УДК $821.161 .2 « 18-19 »$

Назарець В. М., доктор філологічних наук, професор, завідувач кафедри української літератури ПВНЗ «Міжнародний економіко-гуманітарний університет імені академіка Степана Дем'янчука» (м. Рівне)

\title{
ЖАНРОВІ ФОРМИ АДРЕСОВАНОЇ ЛІРИКИ ЛЕСІ УКРАЇНКИ
}

У статті досліджуються дискусійні питання жанрової природи лірики, систематизуються та узагальнюються генологічні кониепиії лірики, розроблені літературознавиями ХX століття. 
Адресована лірика розглядається як метажанровое утворення, щзо вбирає до себе поетичні жанри з підкресленою адресною настановою, інакше кажучи - жанри, в яких предметом зображення виступає комунікація із внутрішньотекстовим адресатом. Аналізуються жанрові форми адресованої лірики (послання, присвята і віршований лист), їхня типологія та поетика.

Ключові слова: ліричний жанр, метажанр, адресована лірика, послання, віршований лист, присвята.

В статье исследуются дискуссионные вопросы жанровой природьг лирики, систематизируются и обобщаются генологические концепщии лирики, разработанные литературоведами $X X$ века.

Адресованная лирика рассматривается как метажанровое образование, которое вбирает в себя поэтические жанры с подчеркнутой адресной установкой, иначе говоря жанры, в которых предметом изображения выступает коммуникация с внутритекстовым адресатом. Анализируются жанровые формы адресованной лирики (послание, посвящение и стихотворное письмо), их типология и поэтика.

Ключевые слова: лирический жанр, метажанр, адресованная лирика, послание, стихотворное письмо, посвящение.

The debatable questions of lyrics genre nature are investigated in the article, lyrics genelogical conceptions, developed by the literary critics of XX century are systematized and summarized.

Addressed lyrics is considered as the genre formation which includes poetic genres with underlined addressed direction, in other words, the genres where communication with the internal text addressee appears as the subject of image. The genre forms of addressed lyrics (message, dedication and a letter, written in verse), their typology and theory of poetry are analysed.

Keywords: lyrical genre, meta-genre, addressed lyrics, message, poetical letter, dedication.

Серед актуальних питань дослідження жанрової специфіки лірики важливе місце посідає проблема метажанрової типології, iï генологічних різновидів. Метажанр найчастіше розглядають як таке синтетичне художнє утворення, яке охоплює спектр окремих жанрів, споріднених за певними структурно-семантичними ознаками. Таким метажанровим утворенням вважаємо адресовану лірику як специфічний художній комплекс, що поєднує три жанри - послання, присвяту та віршований лист.

Мета даної розвідки полягає у тому, щоб дослідити специфіку художнього вияву жанрових форм адресованої лірики у поезії Лесі Українки. Об’єктом аналізу є двадцять сім поетичних текстів Лесі Українки, що належать до адресованої лірики.

Жанрова специфіка адресованої лірики лише починає привертати увагу українських літературознавців. У науковій розвідці Н. Чамати «Жанр послання в українській поезї першої половини XIX ст.» висвітлено питання жанрової 
теорії послання, з’ясовано особливості вияву жанрових форм послання в українській поезії першої половини ХІХ ст. [Чамата 1993].

Послання та функціонально близькі до нього жанри проаналізовано у монографії М. Бондаря «Поезія пошевченківської епохи. Система жанрів». У контексті характеристики жанрів з адресною настановою дослідник пропонує типологію, до якої вводить послання, вірш-заклик, гімн та інвективу [Бондар 1986:154-156].

У літературознавчих розвідках Ю. Клим’юка жанри адресованої лірики досліджено на матеріалі лірики I. Франка в широкому теоретичному контексті. Адресовані жанри, що у дослідника мають дефініцію «референсні», або «прикладні», розглянуто як вид вокативної лірики. Дослідник виділяє три жанрові форми референсної (адресованої) лірики: послання, віршована присвята, епістола» [Клим’юк 2007:13].

Як інвокативну адресовану лірику розглядає інший відомий дослідник творчості I. Франка В. Корнійчук. У науковій розвідці «Жанрова парадигма збірки «Semper tiro» I. Франка» вчений визначає іï як «форму звертання до абстрактного і конкретного адресата, i до себе самого також. /.../ Такі твори власне і належать до інвокативної лірики, у якій перша особа, тобто ліричне «я», посідає окремий пункт у позатекстовому просторі, поступаючись своїм місцем ліричному «ти» - Du Lyrik» [Корнійчук 2004:123]. До інвокативної (адресованої) лірики В. Корнійчук зараховує вірші-заклики i дидактичну апострофу.

Диференціюючи генологічні ознаки жанрових форм адресованої лірики, слід, очевидно, говорити не стільки про чітко окреслені понятійні межі, скільки про певні генологічні тенденції, які, зрештою і дозволяють робити припущення щодо співставлення поетичного твору з тією або іншою жанровою формою адресованої лірики.

Критерієм, що дозволяє теоретично викоремлювати співставні жанрові форми адресованої лірики при цьому виступає власне сам характер адресної авторської настанови, який по-різному виявляє себе у кожному окремому 
випадку. Загальну модель адресованого поетичного тексту теоретично можна моделювати як ситуацію, в якій автор декларує свій естетичний або моральноціннісний досвід світосприймання, але не у формі прямої апеляції до свідомості свого читача, а через посередництво певного внутрішнього адресата, до якого безпосередньо звернена мова. В «ідеальному» жанровому вигляді це звернення набуває форми уявного спілкування, яка більшою чи меншою мірою імітує діалог двох співрозмовників. Автор може не лише звертатися до свого адресата, але й відтворювати його уявні (ймовірні) репліки-відповіді на адресовані йому слова (або ж компонувати текст звернення таким чином, що ймовірна реплікавідповідь буде реконструйована читачем або 3 включених до авторського звернення прямих цитат чи опосередковних алюзій з художніх творів, або ж 3 контексту особистого взаємного спілкування автора із адресатом, якщо така біографічна обставина мала місце).

Зазначена теоретична модель в першу чергу i в загальних рисах характеризує головну жанрову форму адресованої лірики - послання. Дві інші жанрові форми адресованої лірики - віршований лист i присвяту можна відокремити від послання за ознакою певної трансформації характеру авторської адресної настанови.

Тематичні різновиди послання, на нашу думку, найбільш доцільно виокремлювати за ознакою характеру діалогічного контакту між автором та його адресатом. Діалогічну настанову між автором та адресатом, відповідно, може бути реалізовано у площині стосунків: 1) офіційних, суспільногромадських; 2) неофіційних, товариських або дружніх; 3) родинних або сімейних; 4) інтимних. Відтак, можна назвати чотири тематичні різновиди послань - 1) громадянське, 2) дружнє, 3) родинне, 4) любовне.

Громадянське, або ще високе (з огляду на офіційність стосунків, властивих такому контакту) послання генетично споріднене зі своїм найближчим у часі генологічним попередником - високою класицистичною епістолою, 3 якою його зближує пафос емоційної урочистості, повчальноморалізаторський дух, тематика, зумовлена певною мірою злободенними 
потребами громадсько-політичного історичного розвитку суспільства. Громадянське послання має чотири чітко виражені тематичні модифікації, відмінні за характером внутрішньої функціонально-діалогічної настанови.

а) Громадянське послання 3 компліментарною настановою. Для такої тематичної модифікації громадянського послання притаманно: підкреслена урочистість, піднесена емоційна атмосфера i спрямованість на пафосне звеличення та уславлення свого внутрішньотекстового адресата. Таким, зокрема, є послання Лесі Українки «На роковини Шевченка», в якому звеличено постать великого Кобзаря.

б) Громадянське послання 3 дидактичною настановою. Такий тематичний різновид зазвичай відзначається підкреслено піднесеним, урочистим пафосом, проте функціонально спрямованим не на звеличення адресата, а на його просвітництво, повчання, відтак прикметним домінуванням семантики дидактики та моралізаторства (Леся Українка «Жіночий портрет»).

в) Громадянське послання 3 декларативною настановою. Якщо дидактична форма послання передбачає власне повчання з елементами певного просвітництва, але здебільшого без прямих і відвертих закликів до певної дії, то для громадянського послання 3 декларативною настановою властива функціональна спрямованість на прямий і безкомпромісний заклик-спонукання адресата до рішучої дії. В українській ліриці послання 3 декларативною настановою особливого поширення набули в останній третині XIX ст. серед поетів, суспільно-громадська позиція яких була близькою до народницької ідеології.

Яскравим зразком громадянського послання 3 декларативною настановою в адресованій ліриці Лесі Українки є поезія «Товаришці на спомин».

г) Громадянське послання 3 інвективною настановою. Цей семантичний різновид послання близький до дидактичного з огляду на наявність у ньому елементів моралізаторського, повчального пафосу, який, проте, тут має не позитивне (просвітницьке), а різко негативне (критичне) ідейно-тематичне емоційне забарвлення. Мета громадянського послання 3 інвективною 
настановою полягає у дискредитації адресата, доведенні хибності його світоглядних, морально-етичних, естетичних переконань, їхньої невідповідності громадсько-політичним i духовним ідеалам та запитам суспільства, виявлення та спростування їхньої потенційної або й фактичної аморальності чи навіть злочинності. Інвективний пафос притаманний поетичним посланням Лесі Українки «Ворогам» та «Народ пророкові».

На відміну від громадянського дружнє послання не передбачає офіційності ідеологічної настанови, що слугує підгрунтям адресації, i спрямоване на відтворення атмосфери невимушених товариських або безпосередньо дружніх стосунків між автором та його адресатом. Якщо громадянське послання генологічно пов'язане 3 класицистичною епістолою та одою, то дружнє послання генологічно найбільш близьке до елегії, фактично вибудувано на іï основі й у такому вигляді канонізоване у поетичних творах представників сентименталізму та романтизму. У поезії Лесі Українки цей жанровий різновид адресованої лірики представлений такими творами, як-от: «До товаришів», «До товариша».

Тематичний контекст родинного послання зумовлений специфікою стосунків між адресантом та членами його родини. Діалогічна настанова у цьому типі послання, по-перше, майже не стосується суспільно-значущих проблем і окреслена мотивами сімейного затишку, родинного спілкування, ставлення 3 боку одних членів родини до інших тощо. Прикладами можуть слугувати родинні послання Лесі Українки «Колискова», «Веснянка (Сестрі Ользі)», «Братові й сестрі на спомин».

Провідною генологічною ознакою розмежування тематичних різновидів віршованого листа, на нашу думку, можна вважати характер об'єктивованості інформації, декларованої у його діалогічній настанові. 3 огляду на зазначене видається доцільним виокремлювати два основні різновиди віршованого листа: 1) лист інформативного типу і 2) лист рефлективного типу.

Якщо діалогічна настанова віршованого листа інформативного типу передбачає налагодження інформаційного контакту між відправником 
(автором) та отримувачем (адресатом), то для листа рефлективного типу властива семантична переорієнтація цієї настанови на вияв авторських рефлексій щодо власне обставин факту написання або відправлення листа, його цінності для адресанта або адресата.

Адресована лірика Лесі Українки репрезентована взірцями листа інформативного типу, такими, наприклад, як «Уривки 3 листа», але чи не найбільш яскравим зразком є іï лист до брата Михайла, відправлений 3 Колодяжного навесні 1890 року, у якому майже з ідеальною точністю імітовано семантико-стильову структуру побутового прозового листа.

На відміну від послання i, частково, віршованого листа, адресній настанові присвяти властиве певне послаблення семантики діалогічності. 3 огляду на градацію міри послаблення настанови на діалогічність ліричної комунікації у присвяті можна виділити п’ять ऑii тематичних різновидів: 1) присвята ситуативна; 2) присвята асоціативна; 3) присвята латентна; 4) присвята інтроспективна; 5) присвята умовна.

1) Присвята ситуативна. У ситуативній присвяті адресація має найбільш чітку вираженість. Адресний характер ситуативної присвяти детермінує ситуація, привід, що зумовили бажання адресанта відгукнутися на них шляхом певного ліричного волевиявлення. Найчастіше ситуативність такого типу автори присвят доволі часто означують в заголовках або підзаголовках своїх творів, як, наприклад, у поезії Лесі Українки «Подорож до моря (Посвята сім’ї Михайла Ф. Комарова)».

2) Присвята асоичіативна. Діалогічність їі адресної настанови ще більше послаблена 3 огляду на те, що попри відсутність в асоціативній присвяті зовнішніх чітких ознак адресованого тексту, діалогічність у ній збережено у зовнішніх, рамкових елементах структурно-семантичної організації ліричного твору (заголовку, присвяті, епіграфі). Відтак, адресно декларований компонент заголовкового комплексу і зміст ліричного твору взаємопов'язані за принципом психологічного паралелізму: особа адресата асоціюється у свідомості автора 3 певними природними або життєвими картинами, точніше, як слід гадати, саме 
останні слугують психологічним мотиваційним фактором виникнення в авторській уяві асоціації 3 його потенційним адресатом. Так, у поезії Лесі Українки «Вечірня година (Коханій мамі)» картини вечірньої природи навіюють ліричній героїні спогади про материнську любов до своїх дітей, у присвяті «На столітній ювілей української літератури» задекларована заголовком назва стає предметом асоціативних спогадів про легендарні часи, коли поетичне слово було у шані та повазі.

3) Присвята латентна. Латентними присвятами слід вважати такі адресовані поетичні твори, у яких особу адресата, до якого звертається автор, у тексті твору не названо. Не називати особу свого адресата автор може з різних причин - i 3 огляду на обставини побутового або інтимного характеру, й 3 ідеологічних або й естетичних міркувань.

4) Присвята інтроспективна. Інтроспективною $є$ присвята, в якій адресатом звернення $є$ особа самого автора. Такого типу присвяти можна назвати інтроспективними за аналогією із медитативно-описовою, інтроспективною лірикою. Різниця між нею й інтроспективною присвятою полягає в тому, що перша має еготивну форму комунікативної організації тексту, а другій здебільшого надають апелятивної форми, 3 більш або менш очевидно вираженими ознаками автоадресації, часто зі зверненням до себе як до сторонньої, «третьої» особи. Зразками інтроспективної присвяти у адресованій ліриці Лесі Українки є поезї «Сон (Посвята Александрі С-вій)» та «Кримські спогади (Посвята братові Михайлові)».

5) Присвята умовна. Адресатом умовної присвяти виступає певна вигадана людська особа, тваринна або фантастична істота (об’єкти та явища рослинного світу, фізичні феномени тощо). В адресованих текстах Лесі Українки наявні такі різновиди умовного адресата: емоційно-психологічні процеси та морально-етичні переконання («Fa», «До натури», «Mpiє. Не зрадь! Я так довго до тебе тужила...), музичні інструменти, пісні («До мого фортепіано», «Грай, моя пісне!..», «На вічну пам’ять листочкові, спаленому приятельською рукою в непевні часи»), літературні поняття («Слово, чому ти 
не твердая криця...»), місцевість («Кримські спогади»), міфологічні об’єкти та явища («До музи»).

Отже, поезія Лесі Українки представлена широким спектром жанровотематичних різновидів адресованої лірики. Поетеса не лише продовжував літературні традиції цього генологічного типу лірики, започаткованого поетами-романтиками, але й активно вдавалася до художніх експериментів 3 метою трансформації та модифікації жанрових різновидів адресованої лірики, розроблених iï попередниками. Перспективним напрямком подальших досліджень може стати аналіз феномену жанрового синтезу творів адресованої лірики Лесі Українки 3 іншими, певною мірою канонічними, жанровими формами: 1) фольклорними, або такими, які викликають асоціації з уснопоетичними творами («Колискова», «Веснянка (Сестрі Ользі)»); 2) власне літературними формами («Сім струн (Посвята дядькові Михайлові)», «Fa», «До мого фортепіано»).

\section{БІБЛІОГРАФІЯ}

Бондар 1986 - Бондар М. П. Поезія пошевченківської епохи : система жанрів / М. П. Бондар. - К. : Наукова думка, 1986. - 326 с.

Клим’юк 2007 - Клим’юк Ю. І. Жанрова система лірики Івана Франка : автореф. дис. на здобуття наук. ступеня д-ра філол. наук : спец. 10.01.01 Українська література / Ю. І. Клим’юк. - Львів, 2007. - 34 с.

Корнійчук 2004 - Корнійчук В. Жанрова парадигма збірки «Semper tiro» I. Франка / В. Корнійчук // Вісник. - Львів, 2004. - Вип. 3, Ч. 2 : Теорія літератури та порівняльне літературознавство. - С. 118-126.

Чамата 1993 - Чамата Н. П. Жанр послання в українській поезії першої половини XIX ст. / Н. П. Чамата // Другий міжнародний конгрес україністів. Львів : Інститут українознавства ім. І. Крип’якевича, 1993. - С. 137-138. 